\title{
SELECTION OF THE WHEAT GENOTYPES AND RELATED SPECIES WITH RESISTANCE TO MYCOSPHAERELLA GRAMINICOLA
}

\author{
PETR MARTINEK ${ }^{1 *}$, ILONA SVOBODOVÁ ${ }^{1}$, LUBOMÍR VĚCHET $^{2}$
}

${ }^{1}$ Agrotest Fyto, Ltd, Kromeriz
${ }^{2}$ Crop Research Institute, Prague

MARTINEK, P. - SVOBODOVÁ, I. - VĚCHET, L.: Selection of the wheat genotypes and related species with resistance to Mycosphaerella graminicola. Agriculture (Pol'nohospodárstvo), vol. 59, 2013, no. 2, pp. 65-73.

During 2008-2012, field tests of resistance to Mycosphaerella graminicola (Fuckel) J. Schröt. were conducted on a set of selected wheat varieties and related forms. Various M. graminicola isolates obtained from the Crop Research Institute in Prague were used for infection. Resistance of genotypes to three different isolates was tested in each year with the exception of 2009 and 2010, when identical isolates were used. A variant without artificial infection was used as control. Assorted varieties of winter and spring wheat, synthetic hexaploid wheat (SW), tritordeum ( $\times$ Tritordeum Ascherson et Graebner), and one sample of haynaldoticum ( $\times$ Haynaldoticum sardoum Meletti et
Onnis) were tested. The aim was to select potential donors of resistance. The average infection rate for the set of spring wheat varieties over the 5 years was $6.7 \%$ (con-trol $0.5 \%$ ), for tritordeum it was $0.3 \%$ (control $0.1 \%$ ), for SW it was $0.7 \%$ (control $0.1 \%$ ), and for haynaldoticum it was $1.7 \%$ (control $0.2 \%$ ). The infection of winter wheat was $18.6 \%$ (control $3.8 \%$ ). High average resistance was found in tritordeum, haynaldoticum, and some forms of SW. Lower resistance was found in conventional wheat varieties. The results were influenced by the degree of isolate virulence, growing season, and developmental stages of plants at the time of inoculation.

Key words: Septoria leaf blotch; Triticum aestivum L.; synthetic wheat; tritordeum; haynaldoticum

Septoria tritici blotch is one of the most widespread fungal diseases of wheat and also occurs on barley and triticale. The sexual stage of the pathogen is known as Mycosphaerella graminicola (Fuckel) $\mathrm{J}$. Schröt. in Cohn; the asexual stage is Septoria tritici Roberge ex Desmaz. In wheat, it causes yield losses due to premature senescence of leaves, thereby reducing photosynthetic activity. Spots may appear on wheat leaves already in autumn. It is probably ascospore infection that occurs during the vegetation. Ascospores are created in pseudothecia 5-12 weeks after infection (Hunter et al. 1999) and are spread by wind. In spring and summer, the pathogen expands mainly through pycnidiospores that are spread by raindrops falling on the leaf. These are asexual spores that are formed in pycnidia, creating dark dots distributed in elongated, mostly yellow spots on leaves.

Mycosphaerella graminicola is genetically highly variable, as evidenced by the diverse morphology of individual colonies planted using individual pycnidia from even a single spot on the leaf sheet. Samples of different morphology and colour of these colonies are presented on the website of the Crop Research Institute (CRI) in Prague. It has been found that M. graminicola contains two to five different genotypes with differing virulence (Linde $e t$ al. 2002). A comparison of M. graminicola isolates from various geographical locations shows significant differences in the expression of pathogenicity,

Ing. Petr Martinek, CSc. (*Corresponding author), RNDr. Ilona Svobodová, Agrotest Fyto, Ltd, Havlíčkova 2787,76701 Kroměříž, Czech Republic. E-mail: martinek.petr@vukrom.cz, svobodova.ilona@vukrom.cz

Ing. Lubomír Věchet, CSc., Crop Research Institute, Drnovská 507, 16106 Prague 6 - Ruzyně, Czech Republic. E-mail: vechet@vurv.cz 
which appears to be related to differing selection pressures on the population due to previous hosts (Mundt et al. 2003).

In wheat, individual donors carry individual Stb resistance genes with different levels of efficiency specific to particular isolates. However, the great variability in the pathogen gives rise to difficulties in conducting detailed study of the relationships between sets of tested hosts and individual isolates. There often is only small matching of results between years in the field and laboratory tests on leaf segments, and this complicates their interpretation. From a practical point of view, it is crucial to search for new sources of resistance bringing significantly higher levels of resistance. Such sources can be expected to occur in wild forms, but some of these are difficult to use for direct hybridization with normal wheat.

The aims of the present study were to test the resistance levels of current spring and winter wheat varieties to different $M$. graminicola isolates under field conditions and to find new sources of resistance. In addition to common varieties of bread wheat (T. aestivum L.), some artificially created allohexaploid forms were selected.

\section{MATERIALS AND METHODS}

\section{Tested genotypes}

A series of wheat varieties and related species was continuously tested during 2008-2012. Serial numbers were attached to these for more clarity. The samples and years are shown in the following list:

Spring wheat - common varieties tested during 2008-2012:

1 - Amaretto, 2 - Aranka, 3 - Brawura, 4 - Corso, 5 - Granny, 6 - Leguan, 7 - Munk, 8 - Sandra, 9 - Saxana, 10 - Septima, 11 - Sirael, 12 - SW Kadrilj, 13 - SW Kronjet, 14 - Trappe, 15 - Triso, 16 - Vánek, 17 - Vinjett, 18 - Zuzana

Spring wheat - donors of resistance to Fusarium head blight pathogens tested during 2009-2012: 19 - Nobeoka Bozu, 20 - Sumai 3

Spring tritordeum - tested during 2008-2012: 21 - HTC 1323DH, 22 - HTC $1331 \mathrm{aDH}, 23$ - HTC 1331bDH, 24 - HTC 1331cDH, 25 - HT 135aDH,
26 - HT 135bDH, 27 - HTC 2060, 28 - HTC 2071, 29 - HTC 2083, 30 - HTC 2084

Spring haynaldoticum - tested during 2008-2012: 31 - Denti de Cani C.P.

Synthetic spring wheat - tested during 2008-2012: 32 - CROK_1/Ae.sq.(517)

Synthetic spring wheat - tested during 2010-2012: 33 - ALTAR84/Ae.sq.(502), 34 and 35 - ALTAR84/ Ae.sq.(188), 36 and 37 - ALTAR84/Ae.sq.(192), 38 and 39 - D67.2/P66.270//Ae.sq.(659), 40 and $\mathbf{4 1 - D 6 7 . 2 / P 6 6 . 2 7 0 / / A e . s q . ~ ( 2 1 3 ) , ~} 42$ and 43 - 67.2/P66.270//Ae.sq.(217), 44 and 45 - D67.2/ P66.270//Ae.sq.(218), 46 - DOY1/Ae.sq.(188), 47 - REEN/Ae.sq.(458), 48 and 49 - SCA/ Ae.sq.(518), 50 - SNIPE/YAV79//DACK/TEAL/3/ Ae.sq.(629), 51 - Yuk/Ae.sq.(217)

Synthetic spring wheat - tested during 2012:

52 and 53 - ALTAR84/Ae.sq.(198), 54 - ALTAR84/ Ae.sq.(221), 55 - ACO89/Ae.sq.(309), 56 and 57 - 68.112/WARD//Ae.sq.(369), 58 - OY1/ Ae.sq.(447), 59 - 68.111/RGB_U//WARD/3/FGO/4/ RABI/5/Ae.sq.(629), 60 and $\mathbf{6 1}-\mathrm{GO} / \mathrm{USA} 2111 / /$ Ae.sq. (658), 62 - 68.111/RGB_U//WARD/3/ STIL/4/Ae.sq.(781), 63 - CROC_1/Ae.sq.(879), 64 - 68.111/RGB_U//WARD/3/FGO/4/RABI/5/ Ae.sq.(890), 65 - CROC_1/Ae.sq.(518), 66 and 67 - SNIPE/YAV79//Dacian/TEAL/3/Ae.sq.(629), 68 - SNIPE/YAV79//DACK/TEAL/3/Ae.sq.(700), 69, 70 and 71 - TRN/Ae.sq. (700)

Winter wheat - common varieties tested during 2009-2012:

72 - Akteur, 73 - Alibaba, 74 - Arina, 75 - Bakfis, 76 - Baletka, 77 - Banquet, 78 - Barroko, 79 - Batis, 80 - Cleo, 81 - Gene, 82 - Globus, 83 - Helmut, $\mathbf{8 4}$ - Hereward, $\mathbf{8 5}$ - Iridium, $\mathbf{8 6}$ - Code, $\mathbf{8 7}$-Madsen, 88 - Megas, 89 - Milan, 90 - Mulan, 91 - Nova Prata, 92 - Olaf 05, 93 - Olaf 12, 94 - Orlando, 95 - Pitbull, 96 - Rapsodia, 97 - Reaper, 98 - Senat, 99 - Sultan, 100 - Tadorna, 101 - Nancy

In addition to the common varieties of spring and winter wheat registered in the Czech Republic, the following accessions were tested: two major donors of resistance to pathogens causing Fusarium head blight (Sumai 3 and Nobeoka Bozu); 10 lines of hexaploid spring tritordeum; one hexaploid line from southern Italy known as Denti de Cani C.P. (dog 
teeth), described originally as a new allopolyploid species "haynaldoticum" ( $\times$ Haynaldoticum sardoum Meletti et Onnis) but recently as a spontaneous hexaploid wheat (Meletti et al. 1996); and various numbered forms of synthetic hexaploid wheat (SW - synthetic wheat, $2 \mathrm{n}=6 \mathrm{x}=42$, BBAAD'D $\mathrm{B}^{t}$ ) obtained from the International Maize and Wheat Improvement Center (CIMMYT) in Mexico (MujeebKazi et al. 2006; van Ginkel \& Ogbonnay 2007) and which were included into infection tests based on indicative selection in previous field tests. SW was developed by crossing Triticum durum Desf. $(2 \mathrm{n}=$ $4 \mathrm{x}=28$, BBAA) with Aegilops squarrosa L. [synonym Aegilops tauschii (Coss.) Schmalh.] ( $2 \mathrm{n}=2 \mathrm{x}=$ $\left.14, \mathrm{D}^{t} \mathrm{D}^{\mathrm{t}}\right)$. The $\mathrm{SW}$ differs from bread wheat mainly by genome $\mathrm{D}^{\mathrm{t}}$, which can carry genes for new important properties (Arraiano et al. 2001). Pedigrees are presented in the list of SW because tested lines were selected from original Mexican material (some lines with different numbers have the same pedigree).

Tritordeum $(\times$ Tritordeum Ascherson et Graebner) is an artificial cereal species, derived from crosses of wild barley Hordeum chilense Roemer et Schultes $\left(2 \mathrm{n}=2 \mathrm{x}=14 ; \mathrm{H}^{\mathrm{ch}} \mathrm{H}^{\mathrm{ch}}\right)$ with hexaploid or tetraploid wheat (Martin et al. 1999; Rubiales et al. 2000). The forms of SW and tritordeum used are synthetic allohexaploids.

\section{Tested isolates}

A total of 12 different $M$. graminicola isolates were used for testing over 5 years (2008-2012) and are listed in Table 1.

\section{Experimental set-up}

Each of the tested genotypes was sown in the relevant years at Agrotest Fyto, Ltd. Kroměříž in an infection nursery after a preceding crop of winter oilseed rape in four blocks with small plots. Winter and spring genotypes of wheat and related forms, respectively, were sown in autumn and spring at the optimal recommended sowing dates. Individual plots with sown cereals were surrounded by spring mustard, which was used as an isolation crop to prevent the spreading of artificial infection among the blocks of small plots.

Inoculation was conducted each year during the period between full tillering and the beginning of stem elongation (usually in early May) using inocula of the selected pathogen isolates. Each of the three blocks of plots was inoculated with a different isolate in a given year (Table 1) and the fourth block of plots was left without inoculation as a control variant. The isolates used were selected at CRI in Prague and each inoculum was multiplied on maltose-dextrose liquid substrate. Plants were inoculated using a hand sprayer while preferring colder and cloudy weather so as not to wash the inoculum away with rain. Spring and winter crops were inoculated simultaneously. Winter and spring forms differed in their development stages at the time of inoculation. Typically, spring crops were at the full or end of tillering and winter crops were at the beginning of stem elongation. Beginning $4 \mathrm{~d}$ after inoculation, regular sprinkling of the plants from nozzles placed in the stand was provided approximately until the end of June (6 times daily for $15 \mathrm{~min}$ at $2 \mathrm{~h}$ intervals).

$\mathrm{T}$ a

Isolates used for inoculation and year of inoculation (isolates are stored in the CRI collection in Prague)

\begin{tabular}{|c|c|c|c|c|c|c|c|c|c|c|c|c|}
\hline Year of inoculation & \multicolumn{3}{|c|}{2008} & \multicolumn{3}{|c|}{2009 and 2010} & \multicolumn{3}{|c|}{2011} & \multicolumn{3}{|c|}{2012} \\
\hline Isolate number & 1 & 2 & 3 & 4 & 5 & 6 & 7 & 8 & 9 & 10 & 11 & 12 \\
\hline Collection number & $\begin{array}{c}\text { CRI } \\
0361\end{array}$ & $\begin{array}{c}\text { CRI } \\
0016\end{array}$ & $\begin{array}{c}\text { CRI } \\
0108\end{array}$ & $\begin{array}{l}\text { CRI } \\
0324\end{array}$ & $\begin{array}{c}\text { CRI } \\
0323\end{array}$ & $\begin{array}{c}\text { CRI } \\
0271\end{array}$ & $\begin{array}{c}\text { CRI } \\
0044\end{array}$ & $\begin{array}{c}\text { CRI } \\
0360\end{array}$ & $\begin{array}{c}\text { CRI } \\
0282\end{array}$ & $\begin{array}{l}\text { CRI } \\
0311\end{array}$ & $\begin{array}{c}\text { CRI } \\
0345\end{array}$ & $\begin{array}{c}\text { CRI } \\
0352\end{array}$ \\
\hline
\end{tabular}


It can generally be said that during all periods in which the inoculum of $M$. graminicola was spread (May-July), the temperature was above the longterm average, although there was great variation in temperature. During the periods of pathogen development, the years 2008 and 2012 were considerably drier and the years 2009 and 2010 wetter. The year most favouring the natural occurrence of infection was 2010 (with significantly above-average rainfall). As regular sprinkling was conducted in the infection nursery, it can be assumed that the development of the pathogen was more significantly affected by temperature (or air humidity), whereas differences in the availability of water for development of the pathogen after the artificial infection were substantially eliminated by the use of regular sprinkling which simultaneously served as irrigation.

\section{Method of experiment evaluation}

The level of plants' infection was assessed according to the extent of the leaf area covered by pycnidia. The attack was expressed as the sum of the percentage of leaf area with Septoria tritici blotch in the four upper leaves (Briere et al. 1994; Věchet \& Kocourek 1987) in 15 randomly selected productive stems. The evaluation was carried out individually at two time points: the flowering stage for most samples and the milk ripeness stage. Averages of the two observations were considered as final results. The scores obtained are summarized in Table 2 and Figure 1.

\section{RESULTS AND DISCUSSION}

The degree of infection in individual genotypes depends on the virulence of the isolate used, resistance genotype, stage of plant development, and weather conditions of the year. Differences in attack by individual isolates in individual years are evident, for example, on a set of genotypes of spring wheat varieties, which were tested in nearly the same composition in all years (Table 2). This evaluation shows that in 2008, the most virulent isolate was No. $1(5.3 \%)$ and the least virulent isolate No. 3 $(0.5 \%)$; in 2009 , the most virulent isolate was No. 5 $(8.3 \%)$ and the least virulent No. $6(2.1 \%)$; in 2010 , the most virulent isolate was No. $5(5.8 \%)$ and the least virulent isolate No. 6 (3.5\%); in 2011, the most virulent isolate was No. 7 (6.9\%) and the least virulent No. 9 (4.2\%); and in 2012, the most virulent isolate was No. $12(20.4 \%)$ and the least virulent isolate No. 10 (15.4\%). A somewhat different situation occurred in a group of winter wheat varieties, which at the time of inoculation were at later stages of development (early stem elongation). For this set of wheat, the most virulent isolate in 2009 was No. 5, which caused a $19.7 \%$ infection rate, and the least virulent attack was from No. 4 (5.5\%); in 2010, the most virulent isolate was No. $4(48.4 \%)$ and the least virulent isolate No. $6(24.2 \%)$; and in 2011, the most virulent isolate was No. 8 (24.3\%) and the least virulent isolate No. 9 (8.3\%). In 2012, the situation was affected by frost damage and then by very thin stands of some winter crops. In that year, the most virulent isolate was No. 12 with $6.4 \%$ infection of plants and the least virulent isolate was No. 10 with a $4.0 \%$ rate.

Some disparity in the virulence of isolates is evident in the years 2009 and 2010, when identical isolates were used (Table 2, Figure 1). In those years, for a group of spring wheat varieties the most virulent isolate appeared to be No. $5(5.3 \%-2009,5.8 \%$ $-2010)$ and the least virulent No. $6(2.1 \%-2009$, $3.5 \%-2010)$, while the result was somewhat different for the set of winter crops. In 2009, the most virulent isolate was No. $5(19.7 \%)$ in winter wheat varieties, similar to the case of the spring varieties, and the least virulent No. 4 (5.5\%). In 2010, the most virulent isolate was No. $4(48.4 \%)$ and the least virulent No. 6 (24.2\%). Some disparity in the responses of sets of genotypes tested in 2009 and 2010 to the same isolates can be explained by the composition of the two compared sets with same samples in each as well as by differences in the stage of plant development in these sets during inoculation.

The highest infection rate in spring wheat was during 2012 and in winter wheat during 2010. It can be assumed that the high incidence of the disease was conditioned by temperatures above the long-term average and regular water supply from sprinkling, as well as by the plants' being at a growth stage suited to the disease's development. In comparison with other years, 2010 was significantly different in relation to its high rainfall during May and relatively low average temperature in that same month. An- 
other extreme was seen in 2012, when the winter wheat was not well developed due to delayed germination, drought, and partial winterkill. In 2010, the difference in developmental stage between winter and spring wheat varieties was less than in 2011, when winter wheat was more developed and had higher stand density compared with the spring forms. In 2012, the situation was just the opposite, as winter crop stands were damaged and very thin. This resulted, too, in differences as to the degree of infection in winter and spring crops for both years.

In Table 2, infection levels of individual tested genotypes are distinguished by the shade of grey according to the accompanying scale. The shades show good diversity in resistance among individual groups of wheat. Even at first glance, one sees there are genotypes that were always attacked throughout the experiment and, conversely, others that were either not infected at all or only rarely.

$\mathrm{T}$ a

Percentage leaf area infestation of tested spring and winter cereal genotypes by different $M$. graminicola isolates during 2008-2012
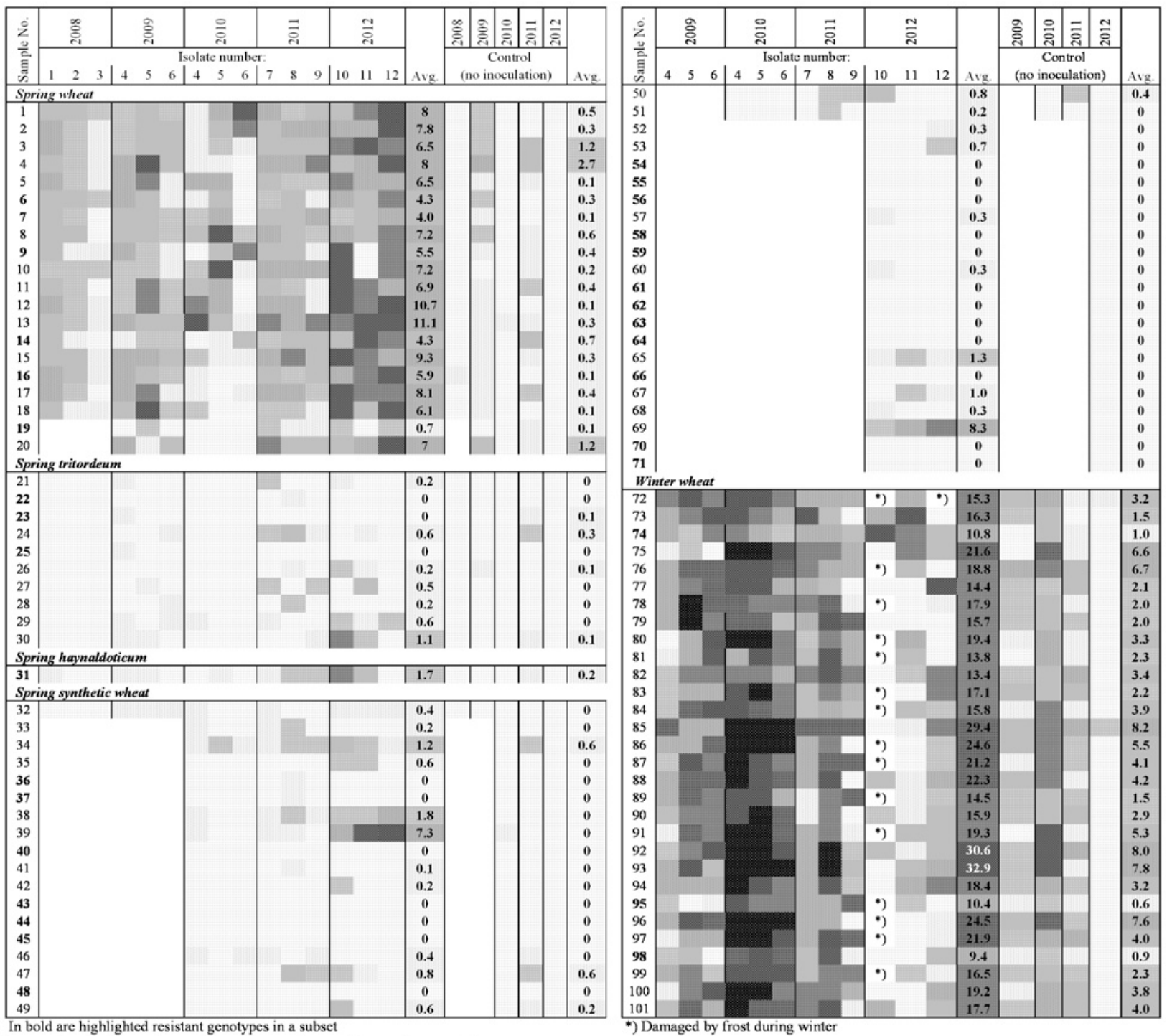

\begin{tabular}{|l|l|l|l|l|l|l|l|l|l|l|}
\hline 0 & $0.1-1$ & $1.1-3$ & $3.1-6$ & $6.1-12$ & $12.1-20$ & $20.1-30$ & $30.1-50$ & $50.1-100$ & Scale [\%] according to the infestation of septoria leaf blotch
\end{tabular}

Range of shades according to the infestation 

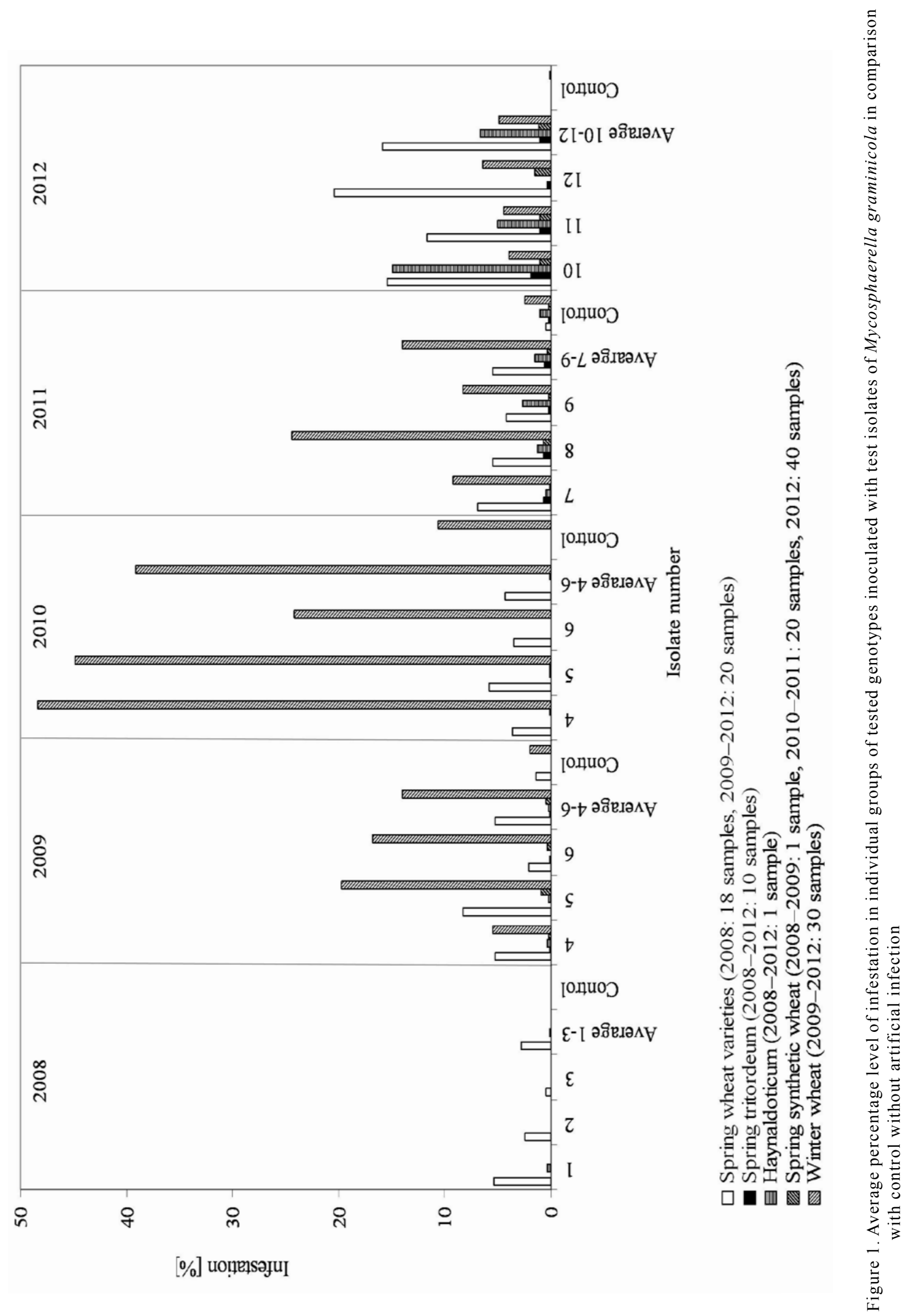
With the year 2012 presenting a distinct exception, those accessions most strongly attacked were always in winter wheat while substantially lower infection was recorded in spring wheat. Conversely, most SW and spring tritordeum were resistant both to the isolates used and to natural infection. If pycnidia were present on leaves, this was mostly in small amounts. It is clear that the occurrence of Septoria tritici blotch is also influenced by the group of genotypes.

On average for the 5 years studied, infection in the set of spring wheat varieties was $6.7 \%$ (control $0.5 \%$ ), in tritordeum $0.3 \%$ (control $0.1 \%$ ), in SW $0.7 \%$ (control 0.1\%), and in Denti de Cani C.P. $1.7 \%$ (control $0.2 \%$ ). The infection of winter wheat was $18.6 \%$ (control 3.8\%) (Figure 1). The most resistant was thus tritordeum, which, unlike common wheat, has the genome $\mathrm{H}^{\text {ch }}$ originating from Hordeum chilense. It can be assumed that the presence of this genome causes increased resistance to $M$. graminicola in this species. In the SW set, the genome $\mathrm{D}^{\mathrm{t}}$ transferred from the wild species Aegilops tauschii can act in a similar way. Samples of SW had been selected for testing in the infection nursery on the basis of previous field experiments. Results had successively confirmed that some SW could indeed be prospective donors. The haynaldoticum which is an old landrace named Denti de Cani C.P. showed greater resistance than did varieties of spring wheat but lower resistance than did tritordeum. In Table 2, the serial numbers of those genotypes with higher rates of resistance to $M$. graminicola are in bold. They are the following:

Spring wheat (tested during 2008-2012):

6 - Leguan, 7 - Munk, 8 - Sandra, 9 - Saxana, 10 - Septima, 14 - Trappe, 16 - Vánek; sources of resistance to Fusarium head blight pathogens (tested during 2009-2012), 19 - Nobeoka Bozu, 20 - Sumai 3

Spring tritordeum (tested during 2008-2012):

22 - HTC $1331 \mathrm{aDH}, 23$ - HTC 1331bDH, 25 - HT 135aDH, 28 - HTC 2071

Spring haynaldoticum (tested during 2008-2012): 31 - Denti de Cani C.P.

Synthetic spring wheat (tested during 2008-2012):

32 - CROK_1/Ae.sq.(517); (tested during 2010-2012): 40 - D67.2/P66.270//Ae.sq.(213),
43 - 67.2/P66.270//Ae.sq.(217), 44 and 45 - D67.2/ P66.270//Ae.sq.(218), 48 - SCA/Ae.sq.(518); (tested in 2012): 54 - ALTAR84/Ae.sq.(221), 55 - ACO89/ Ae.sq.(309), 56 - 68.112/WARD//Ae.sq.(369), 58 - OY1/Ae.sq.(447), 59-68.111/RGB_U//WARD/3/ $\mathrm{FGO} / 4 / \mathrm{RABI} / 5 /$ Ae.sq.(629), 60 and $61-\mathrm{GO} /$ USA2111//Ae.sq.(658),62-68.111/RGB_U//WARD, RESEL/3/STIL/4/Ae.sq.(781), $\mathbf{6 3}$ - CROC_1/ Ae.sq.(879), 64 - 68.111/RGB_U//WARD/3/FGO/4/ RABI/5/Ae.sq.(890), 66 - SNIPE/YAV79//DACK/ TEAL/3/Ae.sq.(629), 70 and 71 - TRN/Ae.sq.(700)

\section{Winter wheat:}

74 - Arina, 95 - Pitbull, 98 - Senat.

Mycosphaerella graminicola belongs to a group of hemibiotrophic pathogens that initially need living tissue to survive and then cause the death of plant tissues. Its genetic specialization in a given substrate is less pronounced than is the case of other pathogens (mildew, rust), which are tied more to the live tissue of their hosts. This results in greater complexity of the relationship between the host and pathogen. At present, there are 15 Stb resistance genes (see Catalogue of gene symbols for wheat) and their localization on chromosomes is also generally known (Goodwin 2007). There have been recorded specific reactions between wheat varieties and $M$. graminicola isolates in controlled laboratory tests on seedlings or leaf segments and on plants under field conditions (Brading et al. 2002; Kema et al. 1996, 1997). The presence of such interactions suggests that the so-called "gene-for-gene" system could operate, where one plant pathogen gene corresponds to one host resistance gene (Brading et al. 2002; Kema et al. 1997). Previous studies have considered the resistance to M. graminicola as qualitative or quantitative traits. In our experiments, the varieties of spring wheat responded variously to different isolates, which confirmed their specific reaction. Considering the wide variability and harmfulness of this disease, it is important to find substantial donors of resistance that would allow breeding varieties with durable resistance. Therefore, a non-host form of resistance typical for Hordeum chilense (determined by genes on chromosome $4 \mathrm{H}^{\text {ch }}$ and genes with small effect on chromosomes $5 \mathrm{H}^{\text {ch }}, 6 \mathrm{H}^{\text {ch }}$, and $7 \mathrm{H}^{\text {ch }}$ ) could be very promising (Rodríguez-Suárez et al. 2011; Rubiales et al. 2000). It is even suggested that this 
type of resistance is still in effect within tritordeum, where there is a concurrence of wheat and barley genomes, and this was confirmed by our results.

The importance of SW species is in their ability to be used as intermediaries to transfer properties from Aegilops tauschii into common hexaploid wheat. Ae. tauschii occurs naturally as the wild type in the Middle East gene centre and is considered an important gene pool for wheat improvement. Activities at the International Maize and Wheat Improvement Center (CIMMYT) focused on the development of $\mathrm{SW}$ in Mexico have led to the breeding of varieties used commercially - and one parent of which was SW (Mujeeb-Kazi et al. 2006; Del Blanco et al. 2001). The resistance gene $S t b 5$ has also been found on the short arm of chromosome 7D in SW (Arraiano et al. 2001; Berzhonsky et al. 2004).

Due to the process of doubling the number of chromosomes, there occur rapid evolutionary changes in the genome in natural and synthetic allopolyploids (Dubcovsky \& Dvořák 2007). This contributes to their greater plasticity and thus the possibility for their broader use in breeding. Unusual cereals used in this experiment are easily crossed with common bread wheat and are usable for transferring resistance.

\section{CONCLUSION}

The most virulent isolates used for artificial infection of spring wheat were: No. 1 (5.3\%) in 2008 , No. $5(8.3 \%)$ in 2009 , No. $5(5.8 \%)$ in 2010, No. 7 (6.9\%) in 2011, and No. 12 (20.4\%) in 2012. As there were different conditions for the pathogen's development in different years, it cannot be definitively stated which one is the most aggressive.

Lower incidence of the pathogen was found in the spring wheat varieties Leguan, Munk, Sandra, Saxana, Septima, Trappe, Triso, Nobeoka Bozu, and Sumai 3, as well as in the winter wheat varieties Pitbull and Senat.

Spring forms of tritordeum and some samples of synthetic hexaploid wheat may be suitable donors of resistance to $M$. graminicola. Their resistance genes could be transferred into common wheat by backcrossing.
The following forms of tritordeum are the most resistant accessions: HTC $1331 \mathrm{aDH}, \mathrm{HTC} 1331 \mathrm{bDH}$, HT 135aDH, and HTC 2071. The most resistant synthetic wheat samples were No. 32 - CROK_1/ Ae.sq.(517), No. 40 - D67.2/P66.270//Ae.sq. (213), No. 43 - 67.2/P66.270//Ae.sq.(217), No. 44 and No. 45 - D67.2/P66.270//Ae.sq.(218), and No. 48 - SCA/Ae.sq.(518). It is more likely that the resistance was found in samples of synthetic wheat (numbers $54,55,56,59,60,63,70$, and 71), which are potentially very valuable donors of resistance to $M$. graminicola.

Specific responses of varieties to individual isolates of M. graminicola were confirmed.

Acknowledgement: The work was supported by the Ministry of Agriculture of the Czech Republic, project no. QH81284.

\section{REFERENCES}

ARRAIANO, L.S. - WORLAND, A.J. - ELLERBROOK, C. - BROWN, J.K.M. 2001. Chromosomal location of a gene for resistance to septoria tritici blotch (Mycosphaerella graminicola) in the hexaploid wheat 'Synthetic 6×'. In Theoretical and Applied Genetics, vol. 103, no. 5, pp. 758-764. DOI: 10.1007/s001220100668.

BERZONSKY, W.A. - HARTEL, K.D. - KIANIAN, S.F. - LEACH, G.D. 2004. Registration of four synthetic hexaploid wheat germplasm lines with resistance to fusarium head blight. In Crop Science, vol. 44, no. 4, pp. 1500-1501. DOI:10.2135/cropsci2004.1500.

BRADING, P.A. - VERSTAPPEN, E.C.P. - KEMA, G.H.J. - BROWN, J.K.M. 2002. A gene-for-gene relationship between wheat and Mycosphaerella graminicola, the septoria tritici blotch pathogen. In Phytopathology, vol. 92, no. 4, pp. 439-45. DOI: 10.1094/PHYTO.2002.92.4.439.

BRIÉRE, S.C. - KUSHALAPPA, A.C. - MATHER, D.E. 1994. Screening for partial resistance to an isolate of crown rust (Puccinia recondita f.sp. avenae) race 264 in oat cultivars and breeding lines. In $\mathrm{Ca}$ nadian Journal of Plant Pathology, vol. 16, no. 1, pp. 49-55.

Del BLANCO, I.A. - RAJARM, S. - KRONSTADT, W.E. 2001. Agronomic potential of synthetic hexaploid wheat-derived populations. In Crop Science, vol. 41, no. 3, pp. 670-676. DOI:10.2135/ cropsci2001.413670x.

DUBCOVSKY, J. - DVOŘÁK, J. 2007. Genome plasticity a key factor in the success of polyploid wheat under domestication. In Science, vol. 318, no. 5833, pp. 1862-1866. DOI: $10.1126 /$ science. 1143986 . 
GOODWIN, S.B. 2007. Back to basics and beyond: increasing the level of resistance to septoria tritici blotch in wheat. In Australian Plant Pathology, vol. 36, no. 6, pp. 532-538. DOI: 10.1071/AP07068.

HUNTER, T. - COKER, T.T. - ROYLE, D.J. 1999. The teleomorph stage, Mycosphaerella graminicola, in epidemics of septoria tritici blotch on winter wheat in the UK. In Plant Pathology, vol. 48, no. 1, pp. 51-57.

KEMA, G.H.J. - ANNONE, J.G. - SAYOUD, R. - VAN SILFHOUT, C.H. - VAN GINKEL, M. - DEBREE, J. 1996. Genetic variation for virulence and resistance in the wheat-Mycosphaerella graminicola pathosystem. 1. Interactions between pathogen isolates and host cultivars. In Phytopathology, vol. 86, no. 2, pp. 200-212. DOI: 10.1094/Phyto-86-200.

KEMA, G.H.J. - VAN SILFHOUT, C.H. 1997. Genetic variation for virulence and resistance in the wheat Mycosphaerella graminicola pathosystem. 3. Comparative seedling and adult plant experiments. In Phytopathology, vol. 87, pp. 266-272. DOI: 10.1094/PHYTO.1997.87.3.266.

LINDE, C.C. - ZHAN, J. - MACDONALD, B.A. 2002. Population structure of Mycosphaerella graminicola: From lesions to continents. In Phytopathology, vol. 92, no. 9, pp. 946-955. DOI: 10.1094/PHYTO.2002.92.9.946.

MARTIN, A. - ALVAREZ, J.B. - MARTIN, L.M. - BARRO, F. - BALLESTEROS, J. 1999. The development of tritordeum: A novel cereal for food processing. In Journal of Cereal Science, vol. 30, no. 2, pp. 85-95. DOI: $10.1006 /$ jcrs.1998.0235.

MELETTI, P. - SBRANA, V. - QUATTRUCCI, E. - GALLI, V. - CAPRONI, E. - CORAZZA, L. - BALMAS, V. - STEFANI, A. - BOZZINI, A. 1996. Denti de cani $(=\times$ Haynaldoticum sardoum $)$ frumento esaploide spontaneo. Caratterizzazione agronomica e tecnologica (Sardegna - Toscana - Calabria - Sicilia) [Denti de cani $(=\times$ Haynaldoticum sardoum $)$ spontaneous hexaploid wheat. Agronomic and technological characterization (Sardinia - Tuscany - Calabria - Sicily)]. In Sementi Elette, vol. 42, no. 6, pp. 33-41. ISSN 0037-1890.
MUJEEB-KAZI, A. - FUENTES-DAVILA, G. - GUL, A. - MIRZA, J.I. 2006. Karnal bunt resistance in synthetic hexaploid wheats $(\mathrm{SH})$ derived from durum wheat $\times$ Aegilops tauschii combinations and in some $\mathrm{SH} \times$ bread wheat derivatives. In Cereal Research Communications, vol. 34, no. 4, pp. 1199-1205. DOI: 10.1556/ CRC.34.2006.4.259.

MUNDT, C.C. - COWGER, C. - MACDONALD, B.A. - ZHAN, J. 2003. Effects of host resistance on Mycosphaerella graminicola populations. In Proceedings of the $6^{\text {th }}$ International Symposium on Septoria and Stagonospora Diseases of Cereals. December 8.-12. 2003, Tunisia, pp. 8-12.

RODRÍGUEZ-SUÁREZ, C. - GIMÉNEZ, M.J. - RAMÍREZ, M.C. - MARTÍN, A.C., GUTIERREZ, N. - ÁVILA, C.M. - MARTÍN, A. - ATIENZA, S.G. 2011. Exploitation of nuclear and cytoplasm variability in Hordeum chilense for wheat breeding. In Plant Genetic Resources - Characterization and Utilization, vol. 9, no. 2, pp. 313-316. DOI: 10.1017/S1479262111000402.

RUBIALES, D. - READER, R.M. - MARTÍN, A. 2000. Chromosomal location of resistance to Septoria tritici in Hordeum chilense determined by the study of chromosomal addition and substitution lines in 'Chinese Spring' wheat. In Euphytica, vol. 115, no. 3, pp. 221224. DOI: 10.1023/A:1004097830103.

Van GINKEL, M. - OGBONNAY, F. 2007. Novel genetic diversity from synthetic wheats in breeding cultivars for changing production condition. In Field Crops Research, vol. 104, no. 1-3, pp. 86-94. DOI: 10.1016/ j.fcr.2007.02.005.

VĚCHET, L. - KOCOUREK, F. 1987. Vliv termínu ošetření na výsev a škodlivost Erysiphe graminis f.sp. hordei na ječmeni jarním [The effect of the time of treatment on the occurrence of Erysiphe graminis f.sp. hordei and the damage it causes to spring barley]. In Ochrana Rostlin, vol. 23, no. 3, pp. 117-124.

Received: January, 15 th 2013 